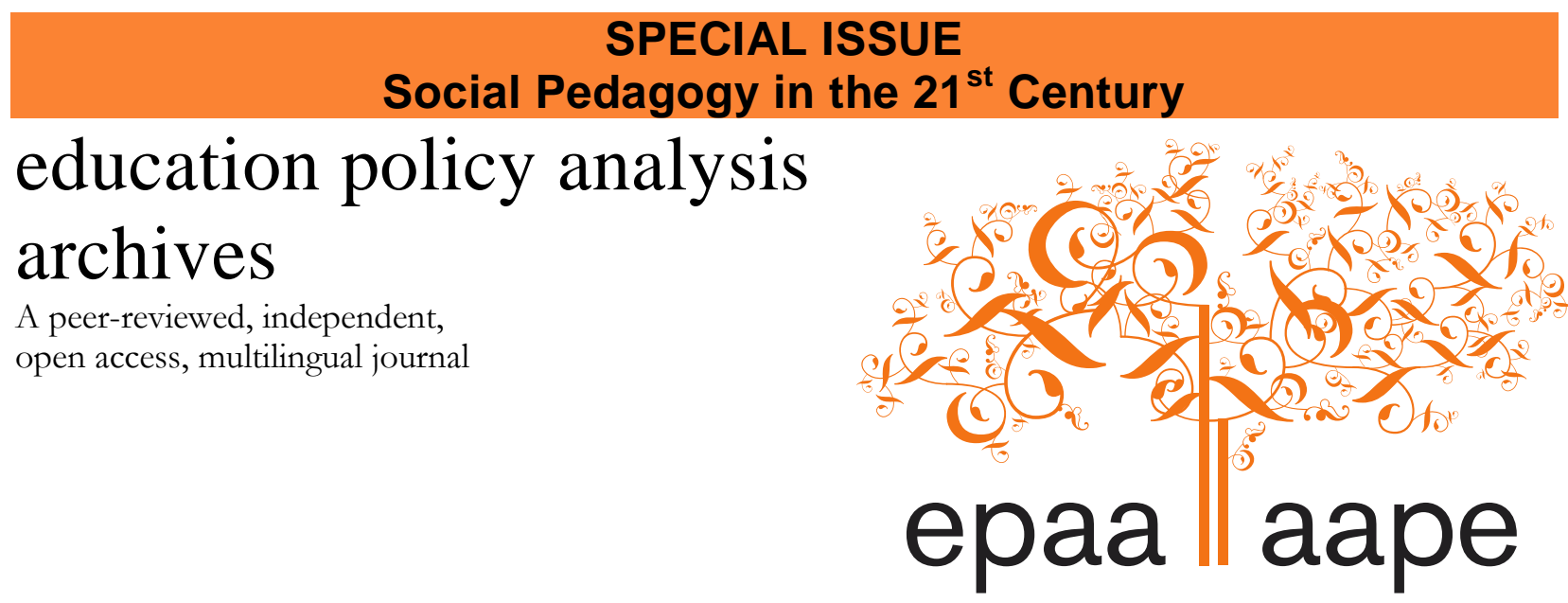

Arizona State University

Volume 21 Number $42 \quad$ April 30 $0^{\text {th }}, 2013$

ISSN 1068-2341

\title{
Variations of Social Pedagogy - Explorations of the Transnational Settlement Movement
}

\author{
Stefan Koengeter \\ Wolfgang Schroeer \\ Hildesheim University \\ Germany
}

Citation: Koengeter, S., Schroeer, W. (2013) Variations of social pedagogy - explorations of the transnational settlement movement. Education Policy Analysis Archives, 21 (42) Retrieved [date], from http://epaa.asu.edu/ojs/article/view/1309. This article is part of EPAA/AAPE's Special Issue on Social Pedagogy in the 21 st Century, Guest Co-Edited by Dr. Daniel Schugurensky and Michael Silver.

\begin{abstract}
Both the German and the international discourses on social pedagogy are shaped by a diachronic perspective on its history, which takes differing national developments as its starting point, and thus sees socio-pedagogical thinking as having its roots in particular nation states. In our article, however, we take a synchronic perspective to show, by means of the transnational development of the settlement movement, that a socio-pedagogical constellation has developed transnationally. After considering examples of the transnational development of the settlement movement in the USA, Germany and Canada, we will reconstruct variants of socio-pedagogical thinking using key publications from the settlement movements. Rather than focusing on historical attempts at definition undertaken by those regarded as the classic proponents of social pedagogy, this essay is concerned with identifying a socio-pedagogical constellation in which various definitions are present simultaneously and can be read from different national, disciplinary, and theoretical positions. The socio-pedagogical constellation, as we derive it from the transnational settlement movement, concentrates on the relationship between a diagnosis
\end{abstract}


of societal conditions, the pedagogical organization of social relations, and the expansion of normatively defined agency. This socio-pedagogical constellation is presented at the end of the essay and positioned in relation to other socio-pedagogical attempts at definition. Keywords: Social Pedagogy, Transnational History, Settlement Movement, 1880-1930, Germany, USA.

\section{Variaciones de la Pedagogía Social. Exploraciones del Movimiento Transnacional de Asentamientos.}

Resumen: Tanto el discurso alemán como el discurso internacional de la pedagogía social está caracterizado por una perspectiva diacrónica con base en su historia, que considera diferentes desarrollos nacionales como puntos de partida, y por tanto interpreta que el pensamiento pedagógico social tiene raíces en estados-naciones particulares. Este artículo, sin embargo, adopta una perspectiva sincrónica y transanacional, e ilustra las variaciones transnacionales de la pedagogía social con el caso del movimiento transnacional de asentamientos. Después de considerar ejemplos del desarrollo transnacional del movimiento de los asentamientos en Estados Unidos, Alemania y Canadá, reconstruiremos las variantes del pensamiento socio-pedagógico utilizando las principales publicaciones de los movimientos de asentamiento. En lugar de centrarnos en los intentos históricos de definición llevada a cabo por aquellos que se consideran como los defensores clásicos de la pedagogía social, este ensayo se enfoca en la identificación de una constelación sociopedagógico en la cual los enfoques y las variaciones en la pedagogía social están presentes sincrónicamente, y pueden ser interpretados desde diferentes posiciones nacionales, disciplinarias y teóricas. La constelación socio-pedagógica, tal como la derivamos del movimiento transnacional de asentamientos, se concentra en la relación entre el diagnóstico de las condiciones sociales, la organización pedagógica de las relaciones sociales, y la expansión de la agencia normativamente definida. Esta constelación socio pedagógico es presentada al final del ensayo y es posicionada en relación con otros intentos socio-pedagógicos de definición del campo.

Palabras-clave: pedagogía social; historia transanacional; movimiento de asentamientos 1880-1930; Alemania; USA.

\section{Mudanças na Pedagogia Social. Pesquisas do movimento transnacional de assentamentos.}

Resumo: Tanto o discurso alemão como o discurso internacional de pedagogia social caracteriza-se por uma perspectiva diacrônica com base em sua história, considerando diferentes desenvolvimentos nacionais como pontos de partida, e, portanto, interpretando o pensamento pedagógico social, como tendo raízes nos estados-nações particulares. Este artigo, no entanto, adota uma perspectiva síncrona e transanacional, e ilustra a variações pedagogia social transnacional com o casos de movimento transnacional assentamentos. Depois de considerar exemplos de desenvolvimento transnacional do movimento de assentamentos nos Estados Unidos, Alemanha e Canadá, reconstruímos as variantes do pensamento sócio-pedagógico com as principais publicações dos movimentos de assentamentos. Em vez de se concentrar em tentativas históricas de definição realizados por aqueles que são considerados clássicos defensores da pedagogia social, este ensaio centra-se na identificação de uma constelação social em que as abordagens pedagógicas e variações da pedagogia social estão presentes de forma síncrona, e pode ser interpretada desde as diferentes posições nacionais, disciplinares e teóricas. A constelação sócio-educativa, como movimento transnacional de assentamentos, centra-se na 
relação entre o diagnóstico da organização social, educacional das relações sociais e da expansão da agência normativamente definido. Esta constelação sócio-pedagógica é apresentada no final do trabalho e está posicionada em relação a outras tentativas de definição do campo sóciopedagógico.

Palavras-chave: pedagogia social, história transanacional; movimento dos colonos 1880-1930, Alemanha, EUA.

\section{Introduction}

Transnational connections have so far gone largely unnoticed in the history of sociopedagogical approaches. On one hand, this can be attributed to the fact that the development of socio-pedagogical approaches in the 19th and early 20th centuries was closely linked to the establishment of the modern concept of the nation-state, and to the corresponding status of citizen. On the other hand historical research in recent years has shown that the constitution of this nationhood was underpinned, on various levels, by approaches, which manifest diverse transnational connections. This perspective can give a broader view of socio-pedagogical approaches since, in recent years, socio-pedagogical thinking has often been analyzed in terms of the national development of a discipline, as a socio-pedagogical profession, or science.

Borrowing Bourdieu's (2000) concept of the "biographical illusion," we can assume that there is a disciplinary illusion in the historiography of social pedagogy. That is, the diachronic context was only produced by the historical construction of social pedagogy as a profession and an academic discipline (cf. Niemeyer, 2005). For example, Oelkers (2005), in his studies on Reformpädagogik (progressive education), has criticized the restrictive view given by a diachronic historiography of theory and instead proposed an analysis of synchronic interrelationships. As a result, our concern in this article is a greater historicization of what social pedagogy is.

We reject representations of history which retrospectively emphasize theoretical consistency as a continuum, and in which social pedagogy in Germany, for example, is constructed as a gradual development of modern socio-pedagogical approaches from Pestalozzi via Natorp to Mollenhauer. Such strategies are not found only within national contexts, however (Müller 1982). Instead, particularly in international contexts, there is a danger of restricting national developments in order to distinguish them from developments in other countries (Kornbeck \& Rosendal Jensen, 2011). More recent attempts to import socio-pedagogical approaches into other countries, such as the transfer of German social pedagogy into Great Britain (Cameron, Petrie, Wigfall, Kleipoedszus, \& Jasper, 2001), also encourage diachronic representations of this kind that are currently popular in Anglo-Saxon countries (Eichstetter \& Holthoff, 2011). This is related to the fact that such narratives seem convincing, and help to facilitate transfers of theory, although these narratives often disregard complex, transnational interconnections. In line with this argument, strategies of "Vereigentlichung" (appropriation or "properization") (Neumann \& Sandermann, 2008, p. 25) are rejected in contemporary research as the focus shifted to the discursive constructions of societal constellations which are processed in socio-pedagogical reasoning (cf. Dollinger, 2006).

If, on the other hand, one analyzes socio-pedagogical approaches in the history of the modern development of nation states from a primarily synchronic point of view, it becomes possible to reconstruct transnational connections which have hitherto scarcely fit into the diachronic constructions of nationally oriented disciplinary developments. Constellations become visible in which transnational connections were vital for socio-pedagogical reflections and endeavors. This is not to say, however, that synchronic perspectives in historiography cannot be subject to a methodological nationalism (Wimmer \& Glick Schiller, 2002). We are simply stating that the pull 
towards a nationally focused disciplinary narrowing in the diachronically oriented observer perspective on the history of social pedagogy which exists in the current state of research can be counteracted by way of a more synchronically oriented analysis.

In what follows we wish to illustrate this point using the example of the settlement movement. In the first third of the $20^{\text {th }}$ century, this movement contained various transnationally linked approaches with the common goal of implementing social reforms on different levels (Köngeter, 2012). In this regard, the settlement movement not only gave substantial support to the development of professional social work (Davis, 1967), but also influenced or helped to develop socio-pedagogical theories and concepts. To date, however, the settlement movement is primarily classified as part of the development of social pedagogy or social work within individual nation states (Lindner, 1997; Scherer, 2004).

In current historical reconstructions of the settlement movement, for example, it is taken for granted that there is a distinction between the British tradition of the settlements, as embodied in Toynbee Hall, and the American version, as typified by Hull House. The assumption is that while Toynbee Hall dealt mainly with the gap between rich and poor, Hull House worked with the ethnic differences caused by the diverse migratory movements in the American cities, in this case Chicago, where "American settlement workers, unlike their English counterparts, had to deal with the problems of the immigrants, and that more than anything else caused the American settlement workers to alter the English model." (Davis, 1967, p. 16) It is implicitly assumed here that the particular national context (Great Britain, USA) determines (or at least influences) the development of tendencies in the settlement movement in each country. However such a perception, which is at least close to methodological nationalism, disregards both the variation within the settlement movement in the USA (Crocker, 1992) and the transnational interrelationships between the actors of the settlement movement. In particular, a review of the widespread migratory movements in the $19^{\text {th }}$ century relativizes the assertion that only the USA had to deal with migrants.

These historical reconstructions also mean that the settlement movements in countries such as Germany, in which they seem not central to the evolution of the discipline, are scarcely noticed, because it is thought that they only became successfully established in the United Kingdom and the USA. Hence historical representations usually focus on the question of why there were not so many settlements in Germany as in Anglo-Saxon countries (Gräser, 2009; Sachße, 1986). In Germany a small number of publications do note e.g. the soziale Arbeitsgemeinschaften (social working groups) in Berlin and other German cities at the beginning of the $20^{\text {th }}$ century (Gräser, 2009; Lindner, 1997; Wendt, 2008), yet little importance is ascribed to these for the subsequent disciplinary development of social pedagogy, which is most often plotted on the basis of educational theories. Conversely, no further consideration is given to the educational orientation of the settlement movement and its significance for social pedagogy.

\section{The settlement house movement}

The settlement house movement emerged in the second half of the $19^{\text {th }}$ century. The historiography of the settlement movement (Hecker, 1967; Meacham, 1987; Woodroofe, 1962) has shown that the starting point for this social movement was the segregation of society, the impact of which was making itself felt - and causing increasing consternation - in the cities of the time, particularly in London, the industrial center of the United Kingdom. In London this sometimes prompted highly emotive descriptions of the living conditions of the workers (Keating, 1973). In the milieu of England's tradition-steeped universities, Cambridge and Oxford, initiatives arose to make their offerings available to the poor. At the same time interest in life in these poor parts of the city 
increased enormously. The so-called slums were discovered by numerous members of the middle classes (Ross, 2007), who tried to develop a deeper understanding of the lives of the poor, partly through sensationalist observations, but also partly through a serious interest in getting to know the slum dwellers and offering them opportunities for social relations (Davis, 1967).

Known as Toynbee Hall, ${ }^{1}$ the first settlement was founded in 1884 by Samuel and Henrietta Barnett in Whitechapel, a particularly poor part of London. The couple had lived for some time in this district, where Samuel Barnett worked as an Anglican clergyman. Both had close contact with protagonists in various welfare organizations (e.g. the Charity Organization Society) and students and graduates from Oxford and Cambridge with an interest in social reform. At the time Toynbee Hall met with broad interest from numerous socio-political actors from different national contexts, such as the USA, Canada, Germany, France, Austria, etc. These developments and the ultimate significance of the settlement movement were decisively influenced by its integration into a transatlantic network of reform movements. Together these constitute an infrastructure through which social reforms and reform programs were spread and popularized across the Atlantic (Rodgers, 1998).

Although it was already clear from the contemporary literature (Addams, 1897; Coit, 1892) that the transatlantic spread of the movement involved substantial processes of transformation, research so far has paid very little attention to the transnational practices in the dissemination of the settlement house concept. This is due to the fact that, in the historical development itself, the actors used national attempts at differentiation to emphasize the legitimation and fit of their own approach for the relevant national context. For example, Jane Addams speaks of "social settlements," in contrast to the English settlement movement, in order to emphasize the reform-oriented position of the American settlement movement (Addams, 1892). Coit (1892), who was of vital importance for the development of the settlements in New York, also criticizes the English settlements for not focusing on the "social reconstruction" of society.

The differences between the nation states were also highlighted from a sociological point of view. In his discussion of the basic functions of the settlements, Mead (1907-1908) argues:

It is an interesting fact that settlements have flourished only where there has been a real democracy. Neither France, with its layers of society, its social castes, nor Germany, with its fundamental assumption that the control of society must take place from above through highly trained bureaus, have offered favorable soil for the growth of settlements. In France it is mutually impossible for men in different social groups to domesticate in other groups. In Germany nobody out of his own immediate milieu undertaking to enter into relations with others is at ease unless he has on a uniform indicating by what right he seeks information, gives advice, or renders assistance (p. 108-109) .

These examples show the rarely questioned assumption that differences emerge along national boundaries. In particular, Mead's reasoning about the dissemination of the settlement idea operates with an unquestioned assumption concerning notions of the nation, democracy, and cultural characteristics.

\section{The transnationality of the settlement movement}

Although from early on the settlement movement developed transnationally, this phenomenon has been largely disregarded in the research thus far. In the following, using the

\footnotetext{
1 The name refers to Arnold Toynbee, an English economic historian and friend of the Barnetts, who worked to improve the living conditions of the poor and who also lived in Whitechapel for a short time.
} 
example of three settlement houses, we show that the development of the settlement movement cannot be described unidirectionally, in the sense of an international transfer of ideas from A to B, but that the settlement movement and its knowledge evolved transnationally, in a network of different actors.

\section{Hull House}

Hull House is regarded as one of the central nodes of the settlement movement, since numerous members of the movement not only visited this settlement in Chicago, but also took its conceptual approach as a model (Bryan \& Davis, 1990). In particular, Jane Addams's high national and international profile and networking (Knight, 2005) encouraged this development. The prominent position of Hull House within the settlement movement, however, makes it difficult to see its development as the result of a transnational development context. Jane Addams's two journeys in Europe between 1883 and 1888, each lasting several years, familiarized her with sociopolitical developments in Europe, and, in particular, with the first London's settlement, Toynbee Hall. In this regard, she was one of the many American social reformers to take inspiration from European social politics (Rodgers, 1998), and was already part of an established network of sociopolitical reformers. Even if the visit to Toynbee Hall marked one of the decisive turning points for Addams, Hull House was by no means only influenced by social reform ideas from the United Kingdom.

In particular, her fellow campaigner Florence Kelley, who also lived in Hull House from 1891, became a determined advocate of socio-political reforms (Sklar, 1995). After graduating from Cornell University in 1882 she went to Europe for several years and studied political science, economics, and law at the University of Zurich. There she came into contact with protagonists of the socialist movement, including Friedrich Engels, whose study on "The Condition of the Working Class in England" she translated into English. Her academic training, coupled with her sociopolitical commitment and experience as a marginalized woman in academia and politics, helped to make her an authority on the social problems arising from industrialization and urbanization. Due to her expertise in the so-called "sweating problem" (Kelley, 1895), i.e. the excessive exploitation of workers, particularly in the clothing industry, she became the chief factory inspector of the state of Illinois. While holding this position, she was given leave to work on the Hull House Maps and Papers (Residents of Hull House, 1895), which she compiled with other residents of Hull House. The Hull House Maps and Papers were modeled on the first systematic urban research, undertaken by Charles Booth in London (Bulmer, Bales, \& Sklar, 1991). In particular, the Hull House maps resemble Charles Booth's maps of the city of London, in which he depicted geographically the distribution of occupations and incomes. The papers, on the other hand, provided a sociopedagogical and socio-political framework for this urban research. In particular, Florence Kelley's essay about the "sweating system" clarifies this socio-pedagogical impetus, as expressed in Kelley's four-word strategy: "investigate, educate, legislate, enforce" (Sklar, 1995, p. 52).

\section{SAG Berlin-Ost (Social Working Group Berlin-East)}

The founding of the best-known settlement in Germany, the Soziale Arbeitsgemeinschaft Berlin-Ost, took place in 1913, at a time when the settlement movement in the USA and the UK had become widely established in the cities. Here, historical reconstructions emphasize the significance of Friedrich Siegmund-Schultze and the inspiration he gained from Toynbee Hall in London. As a Protestant minister he had close connections with Protestant churches in England and was co-founder of the "Church Committee for friendly relations between Great Britain and Germany" (Siegmund-Schultze, 1990, 47). Special mention is made of his visit to the UK in 1908, which took 
him to the poorest parts of East London. There he encountered the work being done in the first settlement in Great Britain, Toynbee Hall, founded in 1884 by Henrietta und Samuel Barnett.

Rarely mentioned, however, is the influence of the American settlements on Germany. For example, Friedrich Siegmund-Schultze visited American settlements such as Hull House for the first time in 1911 (Siegmund-Schultze, 1990). Even more important was Alix Westerkamp's visit to the Chicago Commons. These experiences clearly influenced her decision to become part of the Soziale Arbeitsgemeinschaft, yet her involvement had begun much earlier and coincided with the establishment of the Soziale Arbeitsgemeinschaft in East Berlin. As the first woman to obtain a doctorate in law in Germany (Röwekamp, 2005), she moved to Berlin in 1911 and took charge of the Deutsche Zentrale für Jugendfürsorge (DZfJ, German center for youth care). This was the context for her first contact with Siegmund-Schultze in the summer of 1911, when she advised him to establish the new settlement close to the "Schlesischer Bahnhof," since this area was considered the home of many laborers who were alienated from the church but involved in the communist, socialist, and social democratic parties of the time. Westerkamp managed the DZfJ for two years before leaving on a study trip to Chicago, where she spent several months becoming acquainted with settlement work in the Chicago Commons. As Alix Westerkamp intended to volunteer as a settlement worker, the Chicago Commons was a perfect place to make use of her language abilities and her aspiration to contribute to settlement work. After her return from the USA, she became a close collaborator of Siegmund-Schultze, edited the Akademisch-Soziale Monatsschrift with him from 1917 to 1924 (Röwekamp, 2005), and led the SAG Berlin-Ost after Siegmund-Schultze's involuntary emigration in 1933. The organization of the fourth international settlement conference in Berlin in 1930 undoubtedly represented the highest achievement of the SAG Berlin-Ost in international terms.

\section{St. Christopher}

Finally, the transnational networking of the settlement movement can also be illustrated with the example of St. Christopher House in Toronto. Founded in 1912, St. Christopher was the fourth settlement house in Toronto and represented an important milestone for the Canadian movement. It was a model settlement for four other institutions of the Presbyterian Church in Montreal, Winnipeg, and Vancouver and a training base for many settlement workers. The foundation of St. Christopher was the result of several transnational processes. First, we can find several reports about the settlement house movement from as early as 1889. The strong connections the Presbyterian Church of Canada had to the UK facilitated the important transfer of reform ideas. Secondly, the rapid dissemination of the settlement houses in the neighboring US cities also had a seminal influence on the settlement houses in Canada. Protagonists of the later Canadian settlement movement such as J. J. Kelso, founder of the Toronto Children's Aid Society, and W. L. Mackenzie King, later prime minister of Canada, had close connections to Jane Addams and Hull House.

Thirdly, after the decision to establish St. Christopher House, the Presbyterian Church looked for an experienced person to supervise the project of establishing the chain of settlement houses in Canada. Sara L. Carson from the US was an obvious choice since she had maintained close connections to Toronto's YWCA since 1897, the same year she co-founded Christadora House in New York and committed to the foundation of the first settlement house in Toronto, Evangelia House, in 1902. Carson could be called a transnational professional, moving from the US to Canada and back. She was founder of ten settlement houses altogether; seven in Canada and three in the US (Irving, Parsons, \& Bellamy, 1995, p. 23). Finally, the foundation of St. Christopher also involved important philanthropists such as James Woods, who became interested in the settlement movement 
during extended business trips to Europe and who financially supported the foundation and the maintenance of St. Christopher House.

\section{Socio-pedagogical thinking in the settlement movement}

Our analysis of transnational connections in the settlement movement shows that its actors and organizations are positioned in transnational networks by no means encompassed solely by the settlement movement. On the contrary, various reform movements, associations, and emerging academic disciplines and professions, such as the women's movements, peace movements, labor movements, churches, social work and social pedagogy, etc. play an important role in these transnational processes. Professional trends such as the 'Charity Organizations' or youth welfare work also followed. In the next section, we examine key texts and publications of the settlement movement with reference to their socio-pedagogical implications.

\section{Samuel Barnett: Settlements of university men in great towns (1883)}

One of the founding declarations of the settlement movement - a lecture the above mentioned Canon Samuel Barnett delivered to a group of young men at St. John's College in Oxford in 1883 - clearly shows this linking of social criticism and social work typical of the settlement movement:

Many have been the schemes of reform I have known, but, out of eleven years' experience, I would say that none touches the root of the evil which does not bring helper and helped into friendly relations. (...) Not until the habits of the rich are changed, and they are again content to breathe the same air and walk the same streets as the poor, will East London be 'saved'. Meantime a Settlement of University men will do a little to remove the inequalities of life, as the settlers share their best with the poor and learn through feeling how they live. (Barnett and Barnett, 1915, pp. 104-5)

This quote underscores key motifs characterizing the socio-pedagogical thinking of the settlement approach. The first element highlighted is the concept of "friendly relations," which describes the goal of fundamentally changing the relationship between rich and poor. According to Barnett, rich and poor were no longer to regard each other as helpers and help-seekers (as was the case, structurally, in assistance to the poor based on the individual), but were to interact with one another on an equal footing, as neighbors. Secondly, these reflections are not aimed solely at the poor, but also at changing the attitude of the rich. Lastly, they implicitly show an important shift in the gendered division of labor, which had been taken for granted in the $19^{\text {th }}$ century. While in the $19^{\text {th }}$ century social work in the poor districts had largely been in the hands of women, it was male students from Oxford and Cambridge who were to reside in the settlements. This attempt to instill an awareness of social issues among England's elite was ultimately linked with a socio-pedagogical intention: to bring about a reform of the social conditions themselves.

\section{Jane Addams: A Function of the Social Settlement (1899)}

Addams, as a progressive reformer, regarded this opposition between the "educated" and the "poor" as no longer adequate in a social constellation such as was to be found at the time in the USA with its immigration: 
We do not like to acknowledge that Americans are divided into 'two nations' as her prime minister once admitted of England. ${ }^{2}$ We are not willing, openly and professedly, to assume that American citizens are broken up into classes, even if we make that assumption the preface to a plea that the superior class has duties to the inferior. Our democracy is still our most precious possession, and we do well to resent any inroads upon it, even although they may be made in the name of philanthropy (Addams, 1899, p. 323).

Yet even if Addams did not accept this problematic construction of acute class distinctions for the USA, socio-economic problems were not disregarded at Hull House. Nor were economic differences interpreted solely as cultural conflicts between the different migration groups - as claimed by Lissak (1989). ${ }^{3}$ Instead, Hull House specifically focused on the correlation between ethnocultural and socio-economic differences, for example problematizing the fact that migrant laborers in the context of the so-called sweating system had no time to educate themselves and were thus extremely dependent on individual employers belonging to their own ethnic group (Kelley, 1895). This refutes the assumption imputed to Davis above: that the large number of immigrants meant the settlements in the USA had to vary the Toynbee Hall model. On the contrary, the manner in which the inhabitants of Whitechapel in London (Toynbee Hall) or of the $19^{\text {th }}$ district in Chicago (Hull House) were perceived and their situations were interpreted depended on how the protagonists of the settlement movement constructed the problem.

The following section in Addams's essay gives an indication of the problem construction predominant in Hull House:

It is frequently stated that the most pressing problem of modern life is that of a reconstruction and a reorganization of the knowledge which we possess; that we are at last struggling to realize in terms of life all that has been discovered and absorbed, to make it over into healthy and direct expressions of free living. Dr. John Dewey, of the University of Chicago, has written: 'Knowledge is no longer its own justification, the interest in it has at last transferred itself from accumulation and verification to its application to life.'(Addams, 1899, p. 34)

This shows that not only were the unequal distribution of capital and means of production regarded as crucial problems, but more so the unequal distribution of knowledge within the population and the inadequate use of knowledge to initiate social reforms and developments. With reference to John Dewey and William James, Addams demands knowledge must no longer be considered as a value in and for itself, but with regard to its social distribution and application.

So what role do the social settlements play in this context? From Addams's point of view, two aspects of the question are important. First, the social settlements have the goal of counteracting the unequal distribution of knowledge, and localizing knowledge in the places where it seems most necessary. However, knowledge is not considered without reference to its social context.

2 This is a reference to the novel by Benjamin D'Israeli, English prime minister in 1868 and 1874-1880, who denounced the division between rich and poor in Great Britain with the image of the two nations.

3 This can be discerned, for example, from the so-called Hull House Maps and Papers (Residents of Hull House 1895), which were compiled under the leadership of Florence Kelley. The Maps and Papers were modeled on Charles Booth's monumental study "Life and Labor of the People in East London" (1891) and, like it, produced social maps for the district in which Hull House was situated. Here Kelley not only created maps with the nationalities of the inhabitants, but also provided a graphic record of their incomes. 
Instead knowledge only gains value by proving useful. Therefore the task of the settlement residents is primarily to get to know the situation of the factory workers by becoming a part of their social life. The latest social science methods available at the time were also deployed during this period.

Consequently, settlements were leading actors in the first major surveys as conducted in London and Chicago. Here, the needs of the working classes are not sacrificed to the supposedly higher demands of art, culture and scholarship. If the attempt to get the workers interested in art does not succeed, according to one of Addams's examples, it is because the work of art has no meaning in the context of their circumstances.

Something perhaps even more important becomes clear in this quote at the end of her essay: "A settlement ... makes its appeal upon the assumption that the industrial problem is a social one, and the effort of a settlement ... is valuable largely in proportion as it can make both the working men and the rest of the community conscious of solidarity, and insists upon similarities rather than differences" (Addams, 1899, p. 52). For Addams, the focus of social settlements ultimately lies neither on the working classes and their supposedly insufficient education, nor on the middle classes and their supposed ignorance of the lives of the workers and the poor. Instead the problem of the unequal distribution of knowledge is described as a social problem of industrial, capitalist society. Social settlements' function is to demonstrate the solidarity and cohesion of society. The emphasis, then, is on the establishment of a knowledge context for which social settlements constitute a central link.

\section{Akademische Soziale Monatsschrift (1917-1919)}

The Akademische Soziale Monatsschrift, established in 1917, is the journal of the settlement "Soziale Arbeitsgemeinschaft Berlin-Ost." The socio-pedagogical thinking behind the settlement work in Germany emerges clearly in the message of this publication. Furthermore, in this journal it is possible to observe different variations of social pedagogy which developed in the context of the various transnational connections formed as a result of the settlement movement in Germany. We concentrate here on a small number of texts from the early years of the journal. A more in-depth analysis of this publication is a desideratum in historical research on social pedagogy.

In the first edition of the journal, Friedrich Siegmund-Schultze presents his work in BerlinOst as a continuation of the problem construction which had emerged in Barnett's speech to students in Oxford. He assumes that there are profound "antagonisms" which "have gradually reintensified" (Siegmund-Schultze, 1917, p. 2), by which he means the confrontation between working classes and "ruling classes" (ibid.). In an unpublished pamphlet he varies Benjamin Disraeli's (1845) metaphor of the "two nations", speaking of two peoples who are irreconcilably opposed in Germany, "who do not know or understand each other, who indeed hate each other, and wage war on each other more fiercely than two enemy nations." (Siegmund-Schultze, n.d., p. 1) He therefore sees the main task of settlement work as overcoming this division and bringing about a reconciliation of the hostile "brothers" (ibid.). Against the background of the First World War, he outlines the path to this goal as follows:

For many years of peace and also during the war the Soziale Arbeitsgemeinschaft Berlin-Ost, from which this journal originates, has attempted to create such a community of experience and support in the city. We have ... over the years drawn a few hundred students in Berlin and in other towns into this joint experience, through settling in working class districts, through participating in workers' assemblies and events, through dealing jointly with social problems, and through the various forms of social work. What few did before the war, all must do after the war (Siegmund-Schultze, 1917, p. 3). 
In describing their task in this way, Siegmund-Schultze accentuates an aspect of settlement work that Barnett hardly took into consideration: the creation of a working group as a community of experience and support. He does not put his faith solely in the social education of the individual, for his ultimate concern is the fundamental relationship between different groupings within a society. This is also evident in his definition of social pedagogy, which he wrote many years later, after returning from exile after the Nazi regime and taking up a professorship in social pedagogy in Münster. In this essay he describes a threefold function of social pedagogy: firstly to educate the individual for the community; secondly to educate the group into a community in its behavior towards the individual; and finally, to educate the different groups into a community together (cf. Siegmund-Schultze, 1990, p. 377).

As discussed earlier, another key protagonist of the $S A G$ Berlin-Ost, along with Friedrich Siegmund-Schultze, was Alix Westerkamp. Her decision to become active in the settlement movement in Berlin was inspired by her work as a volunteer in the Chicago Commons. After her return from the USA, she became a close collaborator of Siegmund-Schultze and edited the Akademisch-Soziale Monatsschrift with him from 1917 to 1924 (Röwekamp, 2005).

The Chicago Commons was founded in 1894 by Graham Taylor, who "was one of the first to introduce sociology or social ethics into the curriculum of a theological school" (Davis, 1967, p. 13). While this settlement house had a religious background, its main emphasis lay on social reform and democratic development. Because of this combination of religious and societal impetus, the Chicago Commons was an often-referred-to example, especially in large cities such as Toronto, where the churches used to play an important role (James, 1997). This characteristic also made it interesting for the German settlement movement, especially for the Soziale Arbeitsgemeinschaft Berlin-Ost with its Protestant background.

In the first two volumes of the Akademisch-Soziale Monatsschrift, Westerkamp describes in detail her experiences in Chicago and in the Chicago Commons. Her focus is initially on the contrast with her everyday life in Germany: "In Germany, the class differences constantly assert themselves everywhere. Anyone who has any feeling for this at all senses them as a physical pressure." (Westerkamp, 1917, p. 120) In contrast, in her eyes American life is infused with the conviction that people are, in principle, equal and have equal rights: "It is unbelievably different to Germany - life in the street, in the tram, in the train, in assemblies, in public buildings. The people are ... 'fellow passengers', not just at Christmas, but all year round. The wonderful words of the Declaration of Independence, 'that all men are created equal - they're not literally fulfilled, just as they're not intended to be understood literally, but they're at least somewhat of a reality here. The differences are there ..., but in everyday life those who are at a disadvantage are not constantly reminded of this." (Westerkamp, 1917, p. 120, italicised quotes in English in the original text)

From Westerkamp's perspective, the settlement approach is so successful in the USA because it is based on the equality of humans, despite their social, economic and cultural differences. At the same time the settlement work is a constitutive factor in preventing these differences from turning into antagonisms. In her subsequent letters she mentions key characteristics in this, such as the fundamental willingness and opportunity for democratic co-determination, which may be constitutionally guaranteed, but which is also demanded and enforced by the political activities of the settlement movement. In contrast to Siegmund-Schultze's approach, she focuses her remarks less on education towards community and reconciliation between the groups and more on the facilitation of participation and the political negotiation of opposing interests. Although she leaves no doubt in her letters that she does not see Germany as having the prerequisites necessary for settlement work as it exists in Chicago, she does eventually return to Berlin to take up work in the Berlin $S A G$ there. 
The SAG's approach took a socialist turn under Carl Mennicke. He reported on people's suffering in the "(bourgeois, capitalist) form of life to which we are shackled" Mennicke (1921, p. 40). That suffering, he said, was the starting point for the search for a new form of life. For him, his personal social consternation was what led him to understand and recognize himself as a social being. He understood the establishment of his settlements as a step on the path to creating a socialist society. He believed that the community-destroying power of industrial capitalism and everyday poverty meant the socialist way of life needed to be seen as pedagogy's key task, in order to help people in the communities find self-esteem. "As community (people's innermost taking-oneanother-seriously, 'loving-one-another') can only form and come to life in an atmosphere of selfesteem." (Mennicke, 1922, p. 8) Mennicke was echoing an anti-bourgeois attitude which had just dissociated itself from the caprice of the bourgeois understanding of freedom, in which life choices were seen as being determined by "an individual's arbitrary interest." (Mennicke, 1921, p. 30) From the socialist point of view, he believed freedom was understood in relation to human labor and people's self-esteem.

Mennicke also wrote a piece in the Akademisch-Soziale Monatsschrift reviewing "Deutscher Weltberuf," a work by the well-known German social pedagogue Paul Natorp, which had received a great deal of attention. There were two basic elements of Natorp's "ethic-social" reasoning which Mennicke wanted to see supported: firstly the mutual influence of freedom and community, and secondly "Natorp's passionate words against 'the monster of power." (Mennicke 1919/20, p. 134) Capitalism and militarism, he wrote, had to be overcome as the "embodiments of the power principle." Community, according to Natorp, could only be achieved in freedom, and freedom only in community. No "ideal Volksgemeinschaft (community of the people)" (ibid.) would suppress the individual, because community could only be fulfilled in the differentiation of strengths. "And the more completely the individual becomes autonomous, the stronger his will to community becomes." (ibid., p. 135) Mennicke was highly critical, however, of Natorp's overemphasis on the national consciousness and his consequent distortion of the concept of freedom, as if freedom in community and community in freedom were not already being practiced in other countries, while Natorp was developing "such wonderful ideas about freedom and community here in Germany." (ibid., p. 137) Mennicke mentions the example of the Quakers in England. Furthermore - "as a person who has seen action" - he finds the "German war idealized to a scarcely bearable degree." (ibid., p. 138) As a result, Mennicke's position contrasted those of Siegmund-Schultze and other SAG representatives, which was why he also founded independent social working groups in working-class areas of Berlin (SAG Berlin-Nord).

\section{Socio-pedagogical constellation: agency, social relations und societal diagnosis}

If the approaches of the settlement movement presented here are not classified in a diachronic perspective, each in its own country-specific history of development, but are seen instead in their transnational interrelationships, then variations of social pedagogy which cannot be ascribed to the particular nation-state and welfare-state conditions can be identified in these approaches. These various versions represent possible responses to key elements and questions of a sociopedagogical constellation. This socio-pedagogical constellation is carved out by analyzing the transnational discourse on the settlement approach. In other words, this transnational process of translating the knowledge and concepts of settlement work reveals variations of socio-pedagogical thinking.

What we see in the transnational settlement movement is not a further attempt to define the term, or the formulation of a core problem of social pedagogy, as discussed by Mollenhauer (1959), 
for example. Instead, what we discern is a transnational production of a socio-pedagogical constellation (cf. Dollinger, 2006). Key elements of this socio-pedagogical constellation are a diagnosis of societal conditions, a pedagogical organization of social relations, and the expansion of normatively defined agency.

We present this socio-pedagogical constellation in this final section:

Our discussions and models are based on a diagnosis of society which refers particularly to the social antagonisms in industrial capitalism, and, above all, to urbanization and the dynamic composition of the population due to migration and mobility. Here the different normative assessments are already co-constructed by the 'antidote' (cf. Beck, 2004). These antidotes or interventions, e.g. the creation of relationships between university graduates and other parts of the population - are part of the social diagnosis itself. Diagnoses in the context of the settlement movement are based on the idea that inequality is growing within society. However, they differ greatly in their perception of what comprises that inequality. In Barnett's view it is the gap between rich and poor, while Addams believes it is the unequal distribution of knowledge and a lack of resources to deal with social problems in certain districts. Siegmund-Schultze pinpoints the cracks within an idealized national community, and Mennicke focuses on people's suffering and alienation under industrial capitalism. Finally, in the context of the Chicago settlements Westerkamp places the emphasis on a lack of equal opportunities for political and social participation.

With this diagnosis of society, attention is simultaneously focused on a pedagogical construction of social relations seen as the form of social coexistence and which holds promise for the future. This construction of social relations is regarded as socially productive and becomes the key starting point for expanding the opportunities for action available to all. Ultimately it is constructed as the core of social development or interaction where social relations are repeatedly contrasted with the alienating social conditions. In these different variations of social pedagogy, pedagogy takes on different functions. In the case of Barnett it is about educating individual bourgeois citizens, while Siegmund-Schultze stresses the importance of educating the community. Addams and Westerkamp, in contrast, include socio-pedagogical interventions in their approaches to social politics and social reform, and Mennicke focuses on establishing education as the central momentum behind socialist life choices in the everyday life of the working class.

Finally, the third element of the socio-pedagogical constellation is the definition of agency, which is activated by the potential of social relations. Social division is regarded as oppressive and as a restriction on agency. Social relations, in turn, become the starting point for pedagogical action, which is supposed to lead to the activation and expansion of agency of all those involved. This expansion of agency by means of a pedagogical reorganization of social relations aims to overcome diagnosed societal problems. However, there are also differences between the various positions when it comes to their understanding of agency. While Siegmund-Schultze sees agency as normatively aligning individuals to an imagined community, Barnett focuses on enlightened citizens with a social conscience bringing about social reform. Addams, on the other hand, starts out from the concrete social conditions of the slums, looking for means of extending residents' agency. Westerkamp takes a similar path as regards extending workers' opportunities for participation. Mennicke links agency to worker families' daily struggles and their need for social education.

This general socio-pedagogical constellation, which invites a reorganization of the relationship between agency, social relations and societal context, is defined in different variations in social pedagogy in general and in the settlement movement in particular. Thus, in the settlement movement, for example, social relations are seen at one moment as the starting point for the creation of a community, at another in terms of their necessary differences regarding various forms of knowledge. The perspective we propose here is not aimed at (re)constructing such concepts as a 
generative core of unidirectional development, but rather at highlighting transnational connections in various approaches, in order to draw attention to international and epochal constellations of socio-pedagogical thinking.

\section{References}

Addams, J. (1892). The Subjective Necessity for Social Settlements. In J. Addams, R. A. Woods, F. J. O. S. Huntington, F. H. Giddens \& B. Bosanquet (Eds.), Philanthropy and social progress. Seven essays (pp. 1-26). New York: T.Y. Crowell.

Addams, J. (1897). Social Settlements. In I. C. Barrows (Ed.), Proceedings of the National Conference on Charities and Corrections (pp. 338-346). Boston, Mass.: Geo. H. Ellis.

Addams, J. (1899). A Function of the Social Settlement. The Annals of the American Academy of Political and Social Science, 13(3), 33-55.

Beck, U. (1988). Gegengifte. Die organisierte Unverantwortlichkeit. Frankfurt a.M.: Suhrkamp.

Bourdieu, P. (2000). The biographical illusion. In J. Evans, P. Du Gay \& P. Redman (Eds.), Identity: a reader (pp. 297-303). London: SAGE in association with The Open University.

Bryan, M. L. M., \& Davis, A. F. (1990). 100 years at Hull-House. Bloomington: Indiana University Press.

Bulmer, M., Bales, K., \& Sklar, K. K. (1991). The Social survey in historical perspective, 1880-1940. Cambridge ; New York: Cambridge University Press.

Cameron, C., Petrie, P., Wigfall, V., Kleipoedszus, S., \& Jasper, A. (2001). Final report on the social pedagogy pilot programme: development and implementation.

Coit, S. (1892). Neighbourhood Guilds. London: Swan Sonnenschein \& Co.

Crocker, R. H. (1992). Social work and social order: the settlement movement in two industrial cities, 1889 1930. Urbana: University of Illinois Press.

Davis, A. F. (1967). Spearheads for reform: the social settlements and the progressive movement, 1890 - 1914. New York: Oxford Univ. Press.

Dollinger, B. (2006). Die Pädagogik der sozialen Frage. (Sozial-)Pädagogische Theorie vom Beginn des 19. Jabrbunderts bis zum Ende der Weimarer Republik. Wiesbaden: VS-Verlag.

Disraeli, B. (1845). Sybil; or, the two nations. London: Colburn.

Eichstetter, G., \& Holthoff, S. (2011). Social Pedagogy as an Ethical Orientation towards Working with People - Historical Perspectives. Children Australia, 36(4), 176-186.

Gräser, M. (2009). Woblfahrtsgesellschaft und Woblfahrtsstaat: bürgerliche Sozialreform und Welfare State Building in den USA und in Deutschland, 1880 - 1940. Göttingen: Vandenhoeck \& Ruprecht.

Hecker, M. (1967). Die Entwicklung der englischen Settlementbewegung und der Wandel ibrer Arbeitsformen. Erlangen.

Irving, A., Parsons, H., \& Bellamy, D. (1995). Neighbours: Three Social Settlements in Downtown Toronto. Toronto: Canadian Scholars' Press.

James, C. L. (1997). Gender, Class and Ethnicity in the Organization of Neighbourhood and Nation: The Role of Toronto's Settlement Houses in the Formation of the Canadian State, 1902 to 1914. University of Toronto, Toronto.

Keating, P. J. (1973). Fact and Fiction in the East End. In H. J. Dyos \& M. Wolff (Eds.), The Victorian city: images and realities (pp. 585-602). London: Routledge \& Paul.

Kelley, F. (1895). The Sweating-System. In Residents of Hull House (Ed.), Hull-House Maps and Papers: A Presentation of Nationalities and Wages in a Congested District of Chicago together with Comments and Essays on Problems Growing Out of the Social Condition (pp. 27-48). Boston: Thomas Y Crowell. 
Knight, L. W. (2005). Citizen: Jane Addams and the struggle for democracy. Chicago: University of Chicago Press.

Kornbeck, J., \& Rosendal Jensen, N. (Eds.). (2011). Social pedagogy for the entire lifespan - Volume 1. Bremen: Europäischer Hochschulverlag.

Lindner, R. (Ed.). (1997). "Wer in den Osten geht, geht in ein anderes Land" - Die Settlementbewegung in Berlin zwischen Kaiserreich und Weimarer Republik. Berlin: Akad.-Verl.

Mager, Karl (1844). Schule und Leben. Glossen zu Dr. Curtmann's Preisschrift (Schluss). Pädagogische Revue, 8(5), 395-409

Meacham, S. (1987). Toynbee Hall and social reform 1880 - 1914: the search for community. New Haven: Yale Univ. Pr.

Mead, G. H. (1907-1908). The Social Settlement: Its basis and function. University of Chicago Record, $12,108-110$.

Mennicke, C. (1919/1920). Das Nationalbewußtsein im Lichte sozialen Denkens. In: SozialAkademische Monatsschrift, 3, 133-141.

Mennicke, C. (1921). Sozialistische Lebensgestaltung. Sorialistische Lebensgestaltung, 1, 6-10, 28-33, 3545.

Mennicke, C. (1922). Entgegnung. Blätter für religiösen Sozialismus, 3, 8-10.

Mollenhauer, K. (1959). Die Ursprünge der Sozialpädagogik in der industriellen Gesellschaft. Weinheim: Beltz.

Müller, C. W. (1982). Wie Helfen zum Beruf wurde. Weinheim: Beltz.

Natorp, P. (1894). Religion innerhalb der Grenzen der Humanität. Ein Kapitel zur Grundlegung der Soz̧ialpädagogik von Paul Natorp. Freiburg i. B.: Mohr.

Niemeyer, C. (2005). Klassiker der Sozialpädagogik. Einführung in die Theoriegeschichte einer Wissenschaft. 2. Ed. Weinheim: Juventa.

Oelkers, J. (2005). Reformpädagogik. Eine kritische Dogmengeschichte. Weinheim: Juventa.

Residents of Hull House. (1895). Hull-House Maps and Papers: A Presentation of Nationalities and Wages in a Congested District of Chicago together with Comments and Essays on Problems Growing Out of the Social Condition. Boston: Thomas Y Crowell.

Rodgers, D. T. (1998). Atlantic crossings : social politics in a progressive age. Cambridge, Mass.: Belknap Press of Harvard Univ. Press.

Ross, E. (2007). Slum travelers: ladies and London poverty, 1860-1920. Berkeley: University of California Press.

Röwekamp, M. (Ed.). (2005). Juristinnen: Lexikon zu Leben und Werk. Baden-Baden: Nomos-Verl.Ges.

Sachße, C. (1986). Mütterlichkeit als Beruf: Sozialarbeit, Sozialreform und Frauenbewegung ; 1871 - 1929. Frankfurt a. M.: Suhrkamp.

Neumann, S., \& Sandermann, P. (2008). Hellsichtige Blindheit. Zur vermeintlichen sozialwissenschaftlichen Wende der sozialpädagogischen Theorie. Widersprüche, 28, 11-30.

Scherer, H. (2004). Die Auswirkungen von Besuchen deutscher sozialer Aktivisten im Londoner Settlement „Toynbee Hall“ auf Entstehung und Konzeption der deutschen Nachbarschaftsheimbewegung, Rundbrief-Verband für Sozial-Kulturelle Arbeit e.V. (Vol. 40, pp. 25-30).

Siegmund-Schultze, F. (1917). Akademisch-Soziale Monatsschrift. Akademisch-Soziale Monatsschrift, 1(1), 2-5.

Siegmund-Schultze, F. (1990). Sozialpädagogik - Aufgaben, Wege und Ziele. München: Kaiser.

Siegmund-Schultze, F. (n.d.). Zwei Völker. Evanglisches Zentralarchiv EZA 626 / I / 6,2. 
Sklar, K. K. (1995). Florence Kelley and the nation's work: the rise of women's political culture, 1830 - 1900. New Haven: Yale University Press.

Wendt, W. R. (2008). Geschichte der sozialen Arbeit 1. Die Gesellschaft vor der sozialen Frage. Stuttgart: Lucius \& Lucius.

Westerkamp, A. (1917). Aus amerikanischen Settlements: Briefe und Tagebuchbläter. AkademischSoziale Monatsschrift, 1(7/8), 120-123.

Wimmer, A., \& Glick Schiller, N. (2002). Methodological nationalism and beyond: nation-state building, migration and the social sciences. Global Networks, 2(4), 301-334.

Woodroofe, K. (1962). From charity to social work in England and the United States. London: Routledge \& Kegan Paul.

\author{
About the Authors \\ Stefan Koengeter \\ Institute for Social Pedagogy and Organization Studies, University of Hildesheim, Marienburger \\ Platz 22, D-31141 Hildesheim, Germany \\ Email: koengeter@uni-hildesheim.de
}

Stefan Koengeter is senior Lecturer at the Institute for Social Pedagogy and Organization Studies, Dr. phil., Educational Scientist (Dipl.), Sociologist (MA). He was post-Doctoral fellow of the Research Training Group on "Transnational Social Support" founded by the German Research Foundation (DFG) (2008-2010) and received a postdoctoral research grant of the Canadian Government on the transnational production of knowledge in Social Work (20102011). Currently, he is co-coordinator of the research project "Higher Education Without Family Support", jointly run by the Hebrew U, Bar-Ilan U and Hildesheim U, editor of a special issue on care leavers in "Diskurs Kindheits- und Jugendforschung" (2012), author of several peer-reviewed articles and books on child and youth welfare.

\title{
Wolfgang Schroeer
}

Institute for Social Pedagogy and Organization Studies, University of Hildesheim, Marienburger Platz 22, D-31141 Hildesheim, Germany

Email: schroeer@,uni-hildesheim.de

Wolfgang Schroeer is Professor for Social Pedagogy at the University of Hildesheim. His writings and research activities range from contributions on child and youth welfare, interculturality and migration, to writings about citizenship, civil society and social policy. Together with Prof. Dr. Cornelia Schweppe, University Mainz, he is training a large number of early-stage and advanced researchers, e.g. in the Research Training Group on "Transnational Social Support" founded by the German Research Foundation (DFG).

\author{
About the Guest Co-Editors \\ Daniel Schugurensky \\ Arizona State University \\ Email: dschugur@asu.edu
}

Daniel Schugurensky is a full professor at Arizona State University, where he has a joint appointment in the School of Public Affairs and the School of Social Transformation. He is the Head of the Area of Justice and Social Inquiry, and the coordinator of the Masters program in 
social and cultural pedagogy. He has written extensively on youth and adult education, community development and participatory democracy. Among his recent authored and coedited books are Ruptures, continuities and re-learning: The political participation of Latin Americans in Canada (Transformative Learning Centre, University of Toronto, 2006), Four in Ten: SpanishSpeaking Youth and Early School Leaving in Toronto (LARED, 2009), Learning citizenship by practicing democracy: international initiatives and perspectives (Cambridge Scholarly Press, 2010), Paulo Freire (Continuum, 2011), and Volunteer work, informal learning and social action (Sense 2013).

\section{Michael Silver}

Arizona State University

Email: Michael.Silver@,asu.edu

Michael Silver is a Research Fellow at the National Center on Education and the Economy and the Center for the Future of Arizona. As a Doctoral Student in Educational Policy and Evaluation, his research focuses on policies affecting educational equity and issues of social justice - particularly those related to historically vulnerable, minority populations. 


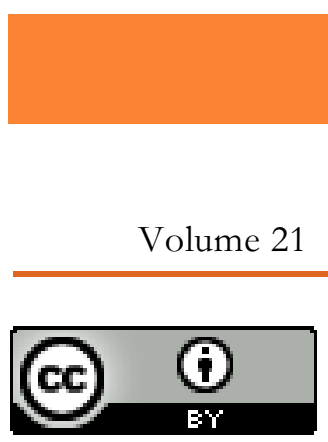

SPECIAL ISSUE

Social Pedagogy in the $21^{\text {st }}$ Century

education policy analysis archives

April $30^{\mathrm{h}}, 2013$

ISSN 1068-2341

Readers are free to copy, display, and distribute this article, as long as the work is attributed to the author(s) and Education Policy Analysis

Archives, it is distributed for non-commercial purposes only, and no alteration or transformation is made in the work. More details of this

Creative Commons license are available at http://creativecommons.org/licenses/by-nc-sa/3.0/. All other uses must be approved by the author(s) or EPAA. EPAA is published by the Mary Lou Fulton Institute and Graduate School of Education at Arizona State University Articles are indexed in CIRC (Clasificación Integrada de Revistas Científicas, Spain), DIALNET (Spain), Directory of Open Access Journals, EBSCO Education Research Complete, ERIC, Education Full Text (H.W. Wilson), QUALIS A2 (Brazil), SCImago Journal Rank; SCOPUS, SOCOLAR (China).

Please contribute commentaries at http://epaa.info/wordpress/ and send errata notes to Gustavo E. Fischman fischman@asu.edu

Join EPAA's Facebook community at https://www.facebook.com/EPAAAAPE and Twitter feed@epaa_aape. 


\section{education policy analysis archives editorial board}

Editor Gustavo E. Fischman (Arizona State University)

Associate Editors: David R. Garcia (Arizona State University), Stephen Lawton (Arizona State University)

Rick Mintrop, (University of California, Berkeley) Jeanne M. Powers (Arizona State University)

Jessica Allen University of Colorado, Boulder

Gary Anderson New York University

Michael W. Apple University of Wisconsin, Madison

Angela Arzubiaga Arizona State University

David C. Berliner Arizona State University

Robert Bickel Marshall University

Henry Braun Boston College

Eric Camburn University of Wisconsin, Madison

Wendy C. Chi* University of Colorado, Boulder

Casey Cobb University of Connecticut

Arnold Danzig Arizona State University

Antonia Darder University of Illinois, UrbanaChampaign

Linda Darling-Hammond Stanford University

Chad d'Entremont Strategies for Children

John Diamond Harvard University

Tara Donahue Learning Point Associates

Sherman Dorn University of South Florida

Christopher Joseph Frey Bowling Green State University

Melissa Lynn Freeman* Adams State College

Amy Garrett Dikkers University of Minnesota

Gene V Glass Arizona State University

Ronald Glass University of California, Santa Cruz

Harvey Goldstein Bristol University

Jacob P. K. Gross Indiana University

Eric M. Haas WestEd

Kimberly Joy Howard* University of Southern California

Aimee Howley Ohio University

Craig Howley Ohio University

Steve Klees University of Maryland

Jaekyung Lee SUNY Buffalo
Christopher Lubienski University of Illinois, UrbanaChampaign

Sarah Lubienski University of Illinois, Urbana-

Champaign

Samuel R. Lucas University of California, Berkeley

Maria Martinez-Coslo University of Texas, Arlington

William Mathis University of Colorado, Boulder

Tristan McCowan Institute of Education, London

Heinrich Mintrop University of California, Berkeley

Michele S. Moses University of Colorado, Boulder

Julianne Moss University of Melbourne

Sharon Nichols University of Texas, San Antonio

Noga O'Connor University of Iowa

João Paraskveva University of Massachusetts, Dartmouth

Laurence Parker University of Illinois, UrbanaChampaign

Susan L. Robertson Bristol University

John Rogers University of California, Los Angeles

A. G. Rud Purdue University

Felicia C. Sanders The Pennsylvania State University

Janelle Scott University of California, Berkeley

Kimberly Scott Arizona State University

Dorothy Shipps Baruch College/CUNY

Maria Teresa Tatto Michigan State University

Larisa Warhol University of Connecticut

Cally Waite Social Science Research Council

John Weathers University of Colorado, Colorado Springs

Kevin Welner University of Colorado, Boulder

Ed Wiley University of Colorado, Boulder

Terrence G. Wiley Arizona State University

John Willinsky Stanford University

Kyo Yamashiro University of California, Los Angeles

* Members of the New Scholars Board 


\section{archivos analíticos de políticas educativas consejo editorial}

Editor: Gustavo E. Fischman (Arizona State University)

Editores. Asociados Alejandro Canales (UNAM) y Jesús Romero Morante (Universidad de Cantabria)

Armando Alcántara Santuario Instituto de Investigaciones sobre la Universidad y la Educación, UNAM México

Claudio Almonacid Universidad Metropolitana de Ciencias de la Educación, Chile

Pilar Arnaiz Sánchez Universidad de Murcia, España

Xavier Besalú Costa Universitat de Girona, España Jose Joaquin Brunner Universidad Diego Portales, Chile

Damián Canales Sánchez Instituto Nacional para la Evaluación de la Educación, México

María Caridad García Universidad Católica del Norte, Chile

Raimundo Cuesta Fernández IES Fray Luis de León, España

Marco Antonio Delgado Fuentes Universidad Iberoamericana, México

Inés Dussel FLACSO, Argentina

Rafael Feito Alonso Universidad Complutense de Madrid, España

Pedro Flores Crespo Universidad Iberoamericana, México

Verónica García Martínez Universidad Juárez Autónoma de Tabasco, México

Francisco F. García Pérez Universidad de Sevilla, España

Edna Luna Serrano Universidad Autónoma de Baja California, México

Alma Maldonado Departamento de Investigaciones Educativas, Centro de Investigación y de Estudios Avanzados, México

Alejandro Márquez Jiménez Instituto de Investigaciones sobre la Universidad y la Educación, UNAM México

José Felipe Martínez Fernández University of California Los Angeles, USA
Fanni Muñoz Pontificia Universidad Católica de Perú

Imanol Ordorika Instituto de Investigaciones Economicas - UNAM, México

Maria Cristina Parra Sandoval Universidad de Zulia, Venezuela

Miguel A. Pereyra Universidad de Granada, España

Monica Pini Universidad Nacional de San Martín, Argentina

Paula Razquin UNESCO, Francia

Ignacio Rivas Flores Universidad de Málaga, España

Daniel Schugurensky Universidad de Toronto-Ontario Institute of Studies in Education, Canadá

Orlando Pulido Chaves Universidad Pedagógica Nacional, Colombia

José Gregorio Rodríguez Universidad Nacional de Colombia

Miriam Rodríguez Vargas Universidad Autónoma de Tamaulipas, México

Mario Rueda Beltrán Instituto de Investigaciones sobre la Universidad y la Educación, UNAM México

José Luis San Fabián Maroto Universidad de Oviedo, España

Yengny Marisol Silva Laya Universidad Iberoamericana, México

Aida Terrón Bañuelos Universidad de Oviedo, España

Jurjo Torres Santomé Universidad de la Coruña, España

Antoni Verger Planells University of Amsterdam, Holanda

Mario Yapu Universidad Para la Investigación Estratégica, Bolivia 


\section{arquivos analíticos de políticas educativas conselho editorial}

Editor: Gustavo E. Fischman (Arizona State University) Editores Associados: Rosa Maria Bueno Fisher e Luis A. Gandin

(Universidade Federal do Rio Grande do Sul)

Dalila Andrade de Oliveira Universidade Federal de Minas Gerais, Brasil

Paulo Carrano Universidade Federal Fluminense, Brasil

Alicia Maria Catalano de Bonamino Pontificia Universidade Católica-Rio, Brasil

Fabiana de Amorim Marcello Universidade Luterana do Brasil, Canoas, Brasil

Alexandre Fernandez Vaz Universidade Federal de Santa Catarina, Brasil

Gaudêncio Frigotto Universidade do Estado do Rio de Janeiro, Brasil

Alfredo M Gomes Universidade Federal de Pernambuco, Brasil

Petronilha Beatriz Gonçalves e Silva Universidade Federal de São Carlos, Brasil

Nadja Herman Pontificia Universidade Católica -Rio Grande do Sul, Brasil

José Machado Pais Instituto de Ciências Sociais da Universidade de Lisboa, Portugal

Wenceslao Machado de Oliveira Jr. Universidade Estadual de Campinas, Brasil
Jefferson Mainardes Universidade Estadual de Ponta Grossa, Brasil

Luciano Mendes de Faria Filho Universidade Federal de Minas Gerais, Brasil

Lia Raquel Moreira Oliveira Universidade do Minho, Portugal

Belmira Oliveira Bueno Universidade de São Paulo, Brasil

António Teodoro Universidade Lusófona, Portugal

Pia L. Wong California State University Sacramento, U.S.A

Sandra Regina Sales Universidade Federal Rural do Rio de Janeiro, Brasil

Elba Siqueira Sá Barreto Fundação Carlos Chagas, Brasil

Manuela Terrasêca Universidade do Porto, Portugal

Robert Verhine Universidade Federal da Bahia, Brasil

Antônio A. S. Zuin Universidade Federal de São Carlos, Brasil 
